\title{
Effects of lysophospholipids on short-term production, nitrogen utilization, and rumen fermentation and bacterial population in lactating dairy cows
}

\author{
C. Lee, ${ }^{1 *}$ D. L. Morris, ${ }^{1}$ J. E. Copelin, ${ }^{1}$ J. M. Hettick, ${ }^{1}$ and I. H. Kwon ${ }^{2}$ \\ ${ }^{1}$ Department of Animal Sciences, Ohio Agricultural Research and Development Center, The Ohio State University, Wooster 44691 \\ ${ }^{2}$ Easy Bio Inc., Seoul, South Korea 06253
}

\section{ABSTRACT}

An experiment was conducted to examine effects of supplemental lysophospholipids (LPL) in dairy cows. Eight ruminally cannulated lactating Holstein cows were used in a replicated $4 \times 4$ Latin square design. Dietary treatments were (1) a dairy ration $[\mathrm{CON} ; 55 \%$ forage and $45 \%$ concentrate on a dry matter (DM) basis], (2) a positive control diet supplemented with monensin (MON; $16 \mathrm{mg} / \mathrm{kg}$ in dietary DM; Elanco Animal Health, Greenfield, IN], (3) a control diet supplemented with low LPL $(0.05 \%$ of dietary DM; Lipidol Ultra, Easy Bio Inc., Seoul, South Korea), and (4) a control diet supplemented with high LPL $(0.075 \%$ of dietary DM). Experimental periods were $21 \mathrm{~d}$ with 14-d diet adaptation and 7-d sample collection. Daily intake and milk yield were measured and rumen contents were collected for fermentation characteristics and bacterial population. Spot urine and fecal samples (8 samples/ cow per period) were collected to determine nutrient digestibility and dietary $\mathrm{N}$ utilization. All data were analyzed using the MIXED procedure of SAS (SAS Institute Inc., Cary, NC; group and cow within group were random effects and treatments, time, and their interaction were fixed effects). Preplanned contrasts were made to determine effect of $\mathrm{MON}$ versus $\mathrm{CON}$, effect of LPL versus MON, and linear effect of increasing LPL. In the current study, responses to MON generally agreed with effects of monensin observed in the literature (increased milk yield and feed efficiency but decreased milk fat content). Supplementation of LPL to the diet did not alter DM intake but linearly increased milk yield, resulting in increases in feed efficiency (milk yield/DM intake) and milk protein and fat yields. However, total-tract digestibility of DM and organic matter tended to be lower (60.9 vs. $62.2 \%$ and 61.8 vs. $63.1 \%$, respectively) for LPL compared with CON. Linear increases in milk $\mathrm{N}$ secretion and

Received October 1, 2018.

Accepted December 18, 2018.

*Corresponding author: Lee.7502@osu.edu decreases in urinary $\mathrm{N}$ excretion were observed with increasing LPL in the diet. A slight decrease in acetate proportion in the rumen for LPL was found. Relative to MON, very few bacteria in the rumen were affected with increasing LPL. In conclusion, LPL is a potential feed additive that can increase milk yield and components and dietary $\mathrm{N}$ utilization. However, more studies with large numbers of animals are needed to confirm the effect of LPL on production. Similar positive effects on production were observed between LPL and MON, but individual mechanisms were likely different according to ruminal fermentation characteristics. Further studies are needed to explore the mode of action of LPL in dairy cows.

Key words: lysophospholipid, production, nitrogen utilization, lactating dairy cow

\section{INTRODUCTION}

Increasing feed efficiency has been emphasized to enhance sustainability of dairy production because increased feed efficiency can result in improving production of cows and lowering environmental impacts simultaneously (VandeHaar et al., 2016). Manipulation of ruminal fermentation is one of the nutritional approaches to improve dietary nutrient utilization for which various feed additives have been examined. For example, monensin is a widely used feed additive in dairy industry, and supplementation of a diet with monensin can increase milk yield and feed efficiency (energy yield/energy intake; Duffield et al., 2008). However, there is growing concern about using an antibiotic for livestock animals due to potential microbial resistance (Russell and Houlihan, 2003; Doane and Sarenbo, 2014), and the use of monensin for livestock animals as a feed additive in Europe has been banned (Maron et al., 2013).

Lysophospholipids (LPL) could be a potent feed additive to improve production and feed efficiency according to studies with nonruminant animals (Tagesson et al., 1985; Zhao and Kim, 2017) in which increased growth, feed efficiency, and dietary nutrient absorption were observed when diets supplemented with LPL were 
fed to pigs and poultry. It was suggested that LPL increases dietary fat absorption due to its emulsifying property (Zhao et al., 2015) and upregulates various genes in intestinal epithelium (Brautigan et al., 2017) to improve nutrient absorption, resulting in positive production responses to LPL. Therefore, LPL has been used as a promising feed additive to improve feed efficiency in nonruminant animals. However, to our knowledge, only 1 study is available in which LPL as a feed additive was fed to dairy cows to lower risk of milk fat depression (Rico et al., 2017).

Lysophospholipids as a feed additive for dairy cows have potential to improve production and feed efficiency based on studies with other emulsifying agents (e.g., sulfactants) that often increased protease and cellulase enzymatic activities in the rumen and therefore improved fiber digestion in vitro and in vivo (Kamande et al., 2000; Hwang et al., 2008). Furthermore, Jenkins et al. (1989) demonstrated that phospholipids (source of LPL) in the rumen can escape microbial degradation and reach the small intestine. If this is the case, similar positive effects of LPL shown in nonruminant animals can be expected in dairy cows. The hypothesis is that production and feed efficiency of cows will be positively affected by LPL in dairy cows due to increases in dietary nutrient utilization. Therefore, the current study determined the potential use of LPL as a feed additive on ruminal fermentation, $\mathrm{N}$ utilization, and production in lactating dairy cows.

\section{MATERIALS AND METHODS}

Animals involved in this experiment were cared for according to the guidelines of The Ohio State University Animal Care and Use Committee. The committee reviewed and approved the animal use and procedures carried out in the study.

\section{Animals and Experimental Design}

The experiment was carried out at Ohio Agricultural Research and Development Dairy Center, The Ohio State University (Wooster, OH). Ten ruminally cannulated Holstein cows (average \pm SD at the beginning of the experiment; DIM $=156 \pm 18$; milk yield $=34 \pm$ $1.8 \mathrm{~kg} ; \mathrm{BW}=604 \pm 20 \mathrm{~kg}$ ) were housed in individual tiestalls, and 8 out of 10 were used for this study in a replicated $4 \times 4$ Latin square design. The remaining 2 cows were included in the experiment as spares. The experimental cows were grouped by DIM and milk yield into 2 squares (4 cows each), and cows in each square were randomly assigned to the following dietary treatments in each period: (1) a dairy ration of $55 \%$ forage and $45 \%$ concentrate on a DM basis $(\mathbf{C O N}$; a typical Midwestern diet in the United States), (2) the CON diet supplemented with monensin $(16 \mathrm{mg} / \mathrm{kg}$ of DM; Rumensin 90, Elanco Animal Health, Greenfield, IN; MON), (3) the CON diet supplemented with a low level $(0.05 \%$ of dietary DM) of LPL (Lipidol Ultra, Easy Bio Inc., Seoul, South Korea), and (4) the CON diet supplemented with a high level $(0.075 \%$ of dietary DM) of LPL. Dietary ingredients and chemical composition are shown in Table 1. All diets were formulated to be isonitrogenous and isoenergetic and met the requirement of all nutrients according to NRC (2001). All diets were prepared daily and fed to cows as TMR ad libitum (targeting $5 \%$ of refusal) with free access to water.

\section{Measurements and Sample Collection}

The experiment consisted of 4 experimental periods that lasted for $21 \mathrm{~d}$ each (14-d diet adaptation and 7-d sampling). Feed offered and refused was measured daily for daily feed intake, cows were milked twice a day throughout the entire experiment, and milk samples (a.m. and p.m.) from individual cows were collected weekly. All cows were weighted on 2 consecutive days (d 20 and 21) at the end of each experimental period.

Forages (corn silage and alfalfa silage) were sampled weekly for $\mathrm{DM}\left(100^{\circ} \mathrm{C}\right.$ overnight), and $\mathrm{DM}$ of forages was adjusted in the rations weekly. Individual feed ingredients and refusals from individual cows were sampled on d 18, 19, and 20 in each period while spot urine and fecal samples were collected (see details below). Feed samples were composted by period, and refusal samples were composited by cow and period.

Spot fecal and urine samples were collected on d 17 (0300, 1100, and 2000), 18 (0500, 1500, and 2300), and 19 (0800 and 2300) in each period to represent every 3 -h sampling in a $24-\mathrm{h}$ cycle. Fecal samples ( 500 g) were collected at each time point from the rectum of individual cows, and samples were composited by cow and period. The composite samples were immediately dried at $55^{\circ} \mathrm{C}$ for $72 \mathrm{~h}$ and ground to pass a $1-\mathrm{mm}$ screen (Wiley mill; Arthur H. Thomas Co., Philadelphia, PA). Spot urine samples were collected through gently massaging the vulva of individual cows. Samples collected were composited by cow and period on an equal volume basis and acidified with $2 \mathrm{M} \mathrm{H}_{2} \mathrm{SO}_{4}$ to maintain $\mathrm{pH}$ below 3.0.

Ruminal samples were collected from individual cows at $2,4,8$, and $12 \mathrm{~h}$ after feeding on $\mathrm{d} 20$ and 21 as described in Lee et al. (2015). Briefly, whole rumen contents were taken from 5 different locations in the rumen (cranial dorsal, cranial ventral, central, caudal dorsal, and caudal ventral) and mixed thoroughly, and then a subsample was collected. The subsample 
of whole ruminal content was strained via 2 layers of a mesh screen $(0.5 \mathrm{~mm})$. Rumen fluid collected was measured immediately for $\mathrm{pH}$ (AE150 $\mathrm{pH}$ Benchtop meter; Thermo Fisher Scientific, Waltham, MA). Aliquots of ruminal fluid were preserved with $0.5 \mathrm{M} \mathrm{H}_{2} \mathrm{SO}_{4}$ or $25 \%$ meta-phosphoric acid. All samples were frozen in $-20^{\circ} \mathrm{C}$ and thawed to make a composite of these by cow and period before analyses. Whole ruminal content collected $4 \mathrm{~h}$ after feeding was subsampled $(\sim 50 \mathrm{~g})$ and composited by cow and period to determine ruminal bacterial profile. The time point of $4 \mathrm{~h}$ after feeding was chosen because microbial fermentation is active at 2 to $4 \mathrm{~h}$ after feeding according to concentrations of fermentation end products in the rumen (Brask et al., 2015).

\section{Laboratory Analyses}

Composite feed ingredients, refusals, and fecal samples were dried $\left(55^{\circ} \mathrm{C}\right.$ for $\left.72 \mathrm{~h}\right)$ and ground to pass a 1-mm screen (Wiley mill; Arthur A. Thomas Co.). Feed ingredients and refusal samples were submitted to Rock River Laboratory (Watertown, WI) for standard chemical analyses (Rock River Laboratory, 2018). Dried and ground fecal samples were analyzed in house for analytical DM (method 934.01; AOAC International, 2000), ash (method 942.05; AOAC International, 2000), N (Flash 2000 Elemental Analyzer; Thermo Fisher Scientific), and NDF (Ankom200 Fiber Analyzer; Ankom Technology Corp., Fairport, NY) with sodium sulfite and $\alpha$-amylase. In addition, all feeds, refusals, and fe-

Table 1. Feed ingredients and chemical composition (\% of DM unless noted) of the experimental diets

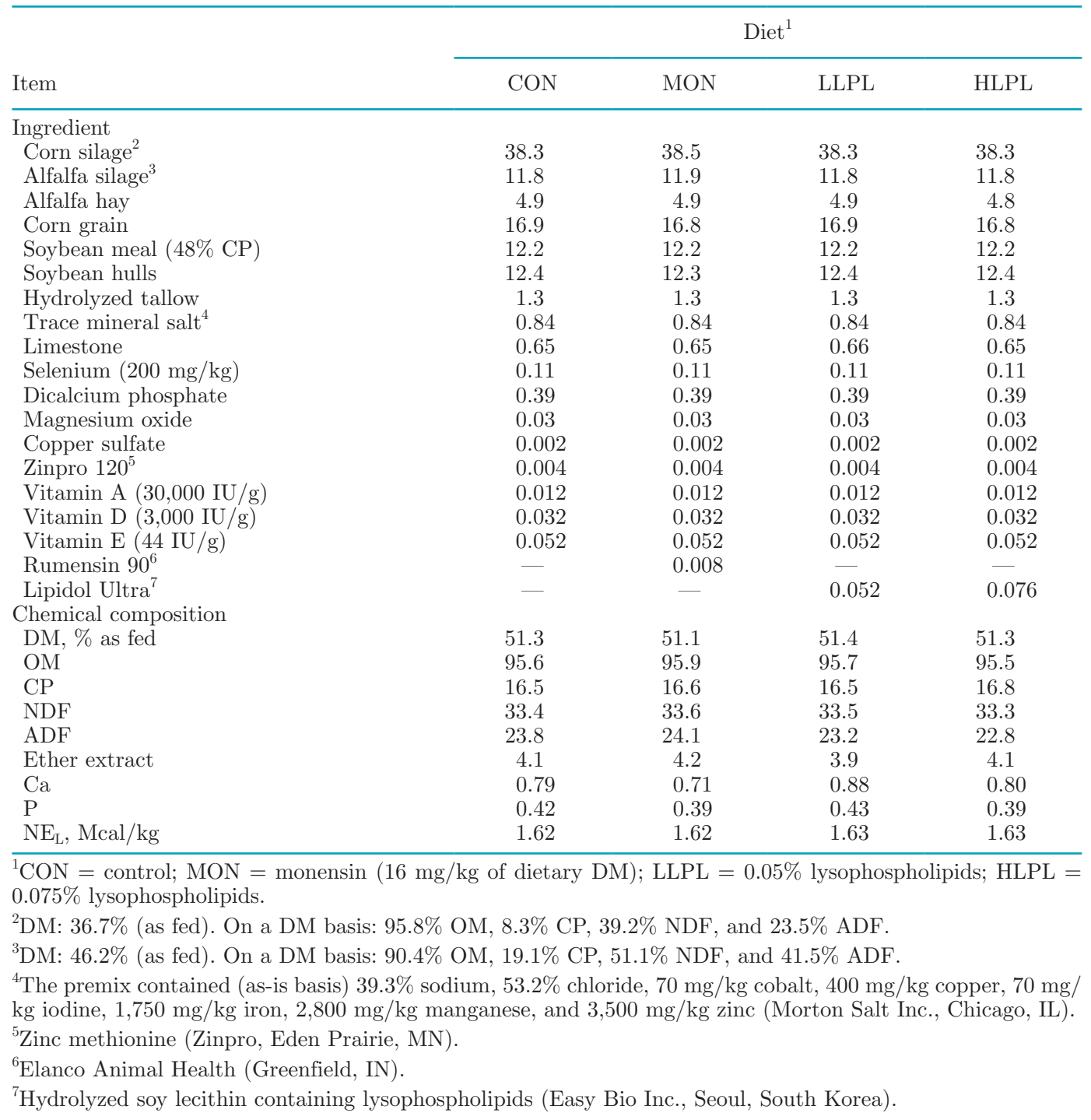


ces were analyzed for indigestible NDF as described by Lee et al. (2012). Briefly, samples were weighed in quadruplicate into filter bags $(25-\mu \mathrm{m}$ pore size; Ankom Technology Corp.) and incubated in 2 cannulated lactating Holstein cows for $12 \mathrm{~d}$. After incubation, bags were rinsed until water ran clear and were analyzed for NDF (Ankom200 Fiber Analyzer) with sodium sulfite and $\alpha$-amylase. Fecal excretion was estimated using indigestible NDF intake and fecal content.

Urine samples were analyzed for N (Flash 2000), creatinine (Kit 500701; Cayman Chemical, Ann Arbor, MI), urea-N (Kit UR107; Randox Laboratories Ltd., Crumlin, UK), uric acid (Stanbio Uric Acid Kit 1045; Stanbio Laboratory Inc., San Antonio, TX), and allantoin (Chen et al., 1990). Urine excretion was estimated based on urinary creatinine concentration assuming a creatinine excretion rate of $29.0 \mathrm{mg} / \mathrm{kg}$ of BW (Valadares et al., 1999; Tebbe and Weiss, 2018). Milk samples were analyzed for total N (Flash 2000) and determined for milk fat, protein, lactose, and MUN (Skalar SAN Plus Segmented Flow Analyzer; Skalar Inc., Norcross, GA) by DHI Cooperative Inc. (Columbus, OH).

All samples of ruminal fluid were centrifuged at $12,000 \times g\left(4^{\circ} \mathrm{C}\right)$ for $10 \mathrm{~min}$, and supernatants were collected and analyzed for ammonia (Chaney and Marbach, 1962). The concentrations of VFA was determined using GC (HP 5890 series, Agilent Technologies, Santa Clara, CA; Mao et al., 2008). Whole ruminal samples collected $4 \mathrm{~h}$ after feeding were analyzed for bacterial populations at Molecular Research DNA (Shallowater, TX) using 16S rDNA bacterial tag-encoded FLX amplicon pyrosequencing (Dowd et al., 2008; Hristov et al., 2012). Briefly, the $16 \mathrm{~S}$ rRNA gene V4 variable region PCR primers 515/806 were used in PCR using the HotStarTaq Plus Master Mix Kit (Qiagen, Germantown, MD). After amplification, PCR products were checked in $2 \%$ agarose gel to determine the success of amplification and the relative intensity of bands. Sequencing was performed at MR DNA (Shallowater, TX) following the manufacturer's guidelines. Sequences were depleted of barcodes and primers; then, sequences $<150$ bp and sequences with ambiguous base calls and with homopolymer runs exceeding 6 bp were also removed. Sequences were denoised, operational taxonomic units were generated, and chimeras were removed. Sequences with identity scores $>95 \%$ were resolved at the species level, between 95 and $97 \%$ at the genus level, between 90 and $95 \%$ at the family level, between 85 and $90 \%$ at the order level, between 80 and $85 \%$ at the class level, and between 77 and $80 \%$ at the phyla level using BLASTn (https://blast.ncbi.nlm.nih.gov/Blast.cgi) against a curated database derived from GreenGenes, RDPII, and NCBI.

\section{Statistical Analyses}

During the first period, 1 of the cows on the CON diet supplemented with a high level of LPL was removed from the experiment due to displaced abomasum, and a spare cow replaced her starting from period 2 . Therefore, all data collected from the cow removed in period 1 were not used in the statistical analyses.

The data for DMI and production (milk, FCM, and ECM yields and feed efficiencies) observed for the last $10 \mathrm{~d}$ of each period were used for statistical analysis (the statistical inference did not differ between the variables from the last $10 \mathrm{~d}$ and those from the 7 - $\mathrm{d}$ collection period) using the MIXED procedure of SAS (SAS 9.4; SAS Institute Inc., Cary, NC). The model used included the fixed effects of diet, period, day, and their 2- or 3-way interactions and the random effects of square and cow within square. Repeated measures with day were included with the covariance structure of $\operatorname{ar}(1)$ according to the lowest Bayesian information criterion. Ruminal fermentation data were analyzed using the same model except that hours were applied to repeated measures. The data of milk composition, nutrient digestibility, $\mathrm{N}$ utilization, and bacterial population were also analyzed using the same model except that repeated measures and time effects were not included in the model. For the data of bacterial population, all species of bacteria that were greater than $0.5 \%$ in total population were selected. The selected bacterial species and their corresponding genus and phylum were analyzed for statistical analysis, where only species and their corresponding genus and phylum that were significantly different among treatments were reported. Preplanned contrasts were applied to determine the difference between CON and MON and between MON and the CON diet supplemented with a low level of LPL plus the CON diet supplemented with a high level of LPL. In addition, the linear and quadratic effects of LPL were determined, for which the coefficients used for the unequal application rates of LPL were obtained using the IML procedure of SAS. Quadratic effects for all dependent variables were not significant and not included in all tables. Statistical differences were declared at $P<0.05$. Differences between treatments with 0.05 $<P<0.10$ were considered as a trend toward significance. Data are presented as least squares means.

\section{RESULTS}

Supplementation of the diet with monensin and LPL did not affect DMI (Table 2). However, increasing LPL in the diet linearly increased $(P \leq 0.022)$ milk yield, $4 \%$ FCM, and ECM and improved $(P \leq 0.039)$ feed 
Table 2. Effects of lysophospholipids on intake and milk production and composition in dairy cows

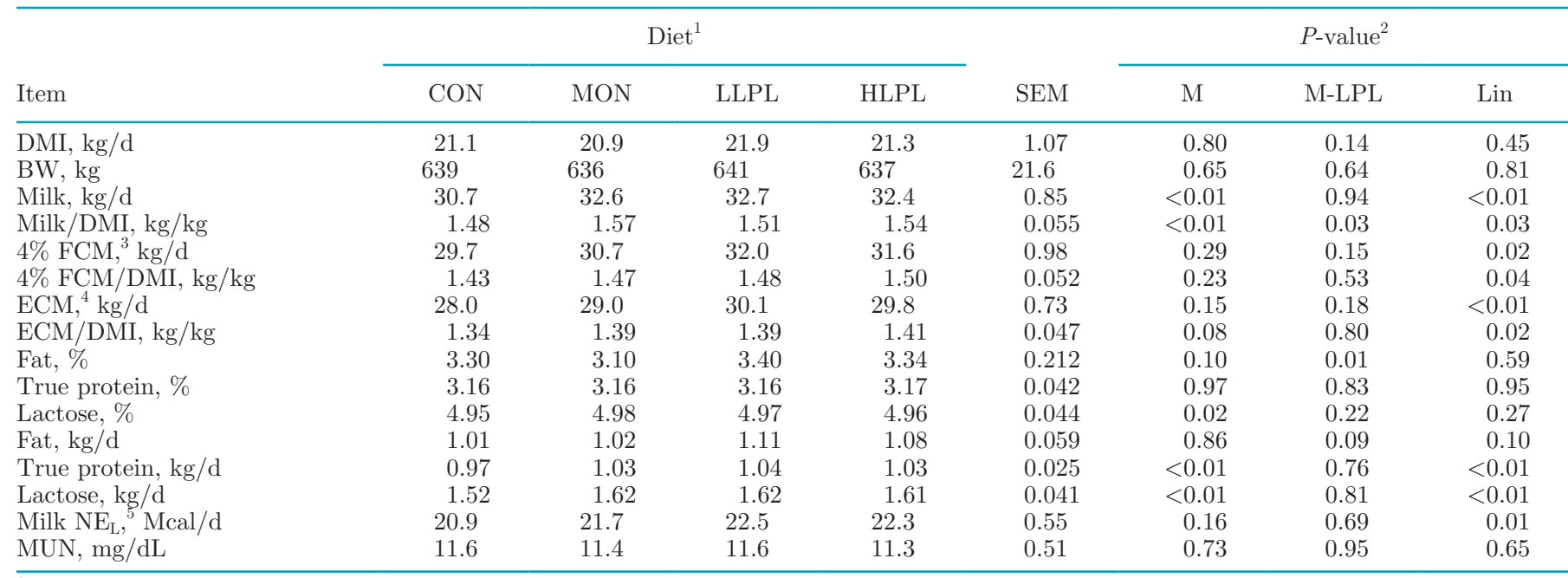

${ }^{1} \mathrm{CON}=$ control; MON $=$ monensin $(16 \mathrm{mg} / \mathrm{kg}$ of dietary DM $) ; \mathrm{LLPL}=0.05 \%$ lysophospholipids; HLPL $=0.075 \%$ lysophospholipids.

${ }^{2} \mathrm{M}=\mathrm{CON}$ versus MON; M-LPL $=\mathrm{M}$ versus LLPL + HLPL; Lin $=$ linear effect of LPL.

${ }^{3} 4 \% \mathrm{FCM}=[$ milk fat $(\mathrm{kg} / \mathrm{d}) \times 16.218]+[$ milk yield $(\mathrm{kg} / \mathrm{d}) \times 0.4324]($ Tyrrell and Reid, 1965).

${ }^{4} \mathrm{ECM}(\mathrm{kg} / \mathrm{d})=\mathrm{kg}$ of milk $\times[(38.3 \times \%$ fat $\times 10+24.2 \times \%$ true protein $\times 10+16.54 \times \%$ lactose $\times 10+20.7) / 3,140](\mathrm{Sjaunja}$ et al., 1990$)$.

${ }^{5} \mathrm{Milk} \mathrm{NE}_{\mathrm{L}}(\mathrm{Mcal} / \mathrm{d})=\mathrm{kg}$ of milk $\times(0.0929 \times \%$ fat $+0.0563 \times \%$ true protein $+0.0395 \times \%$ lactose $)(\mathrm{NRC}, 2001)$.

efficiency [milk, 4\% FCM, and ECM ( $\mathrm{kg} / \mathrm{kg}$ of DMI)]. Supplementing a diet with increasing LPL did not affect milk fat, protein, and lactose content but tended to increase $(P=0.096)$ milk fat yield and increased $(P<$ $0.01)$ milk protein and lactose yields. As a result, milk energy yields linearly increased $(P=0.01)$ with increasing LPL. Increasing LPL in the diet had no effects $(P=0.65)$ on MUN. Similarly, inclusion of monensin in the diet increased milk yield (MON vs. CON; $P<$ $0.01)$ without affecting DMI and therefore increased $(P<0.01)$ milk yield per unit of DMI. However, fat content of milk tended to be lower $(P=0.10)$ and milk lactose concentration and yield were greater $(P \leq 0.02)$ for MON compared with CON without differences in contents and yields of other milk components.
Intake of dietary nutrients and apparent digestibility of these nutrients measured during sample collection of feces ( $3 \mathrm{~d}$ in each experimental period) are shown in Table 3. The MON and LPL diets did not affect $(P \geq$ 0.22 ) intake of DM, OM, CP, and NDF. However, increasing LPL in the diet tended to decrease $(P=0.07)$ apparent digestibility of $\mathrm{DM}$ and $\mathrm{OM}$ without affecting $\mathrm{CP}$ and NDF apparent digestibility. No differences $(P$ $\geq 0.34)$ in apparent digestibility of these nutrients were found between CON and MON.

Nitrogen intake was not different among treatments (Table 4). Increasing LPL in the diet increased $(P=$ $0.024)$ milk $\mathrm{N}$ secretion, but milk $\mathrm{N}$ as proportion of $\mathrm{N}$ intake did not differ among treatments. Similarly, MON tended to increase (162.3 vs. $153.7 \mathrm{~g} / \mathrm{d} ; P=0.09)$

Table 3. Effects of lysophospholipids on intake and nutrient digestibility in dairy cows

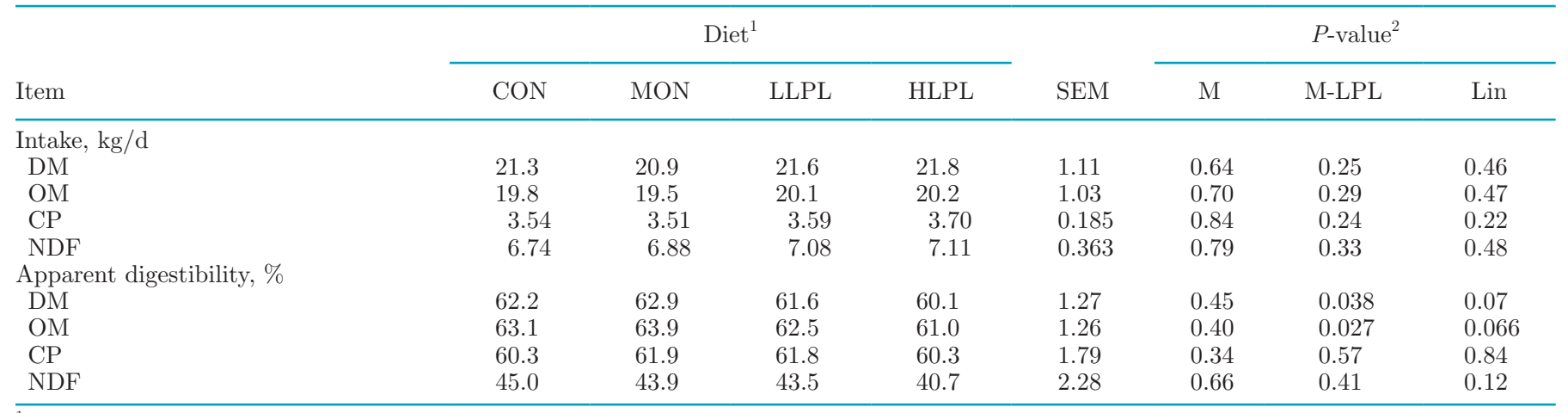

${ }^{1} \mathrm{CON}=$ control; MON $=$ monensin $(16 \mathrm{mg} / \mathrm{kg}$ of dietary DM $) ; \mathrm{LLPL}=0.05 \%$ lysophospholipids; HLPL $=0.075 \%$ lysophospholipids.

${ }^{2} \mathrm{M}=\mathrm{CON}$ versus MON; M-LPL $=\mathrm{M}$ versus LLPL + HLPL; Lin = linear effect of LPL. 
milk $\mathrm{N}$ secretion but did not affect milk $\mathrm{N}$ as proportion of $\mathrm{N}$ intake compared with $\mathrm{CON}$. Fecal $\mathrm{N}$ excretion and that as proportion of $\mathrm{N}$ intake did not differ among treatments. However, LPL decreased $(P=0.016)$ urinary $\mathrm{N}$ excretion in a dose-response manner, and this resulted in a linear decrease $(P=0.023)$ in urinary $\mathrm{N}$ excretion as proportion of $\mathrm{N}$ intake. Similar decreases $(P \leq 0.04)$ in urinary $\mathrm{N}$ excretion and that as proportion of $\mathrm{N}$ intake were observed for MON compared with $\mathrm{CON}$. However, urinary urea-N excretion and urea-N concentration in total urinary $\mathrm{N}$ were not affected by treatments. No differences in uric acid, allantoin, and purine derivatives excretion were observed. When compared with MON, purine derivatives excretion was greater (381.2 vs. $301.9 \mathrm{mmol} / \mathrm{d} ; P=0.027)$ for LPL. No differences in $\mathrm{N}$ retained and that as proportion of $\mathrm{N}$ intake were observed among treatments.

Dietary treatments did not affect ruminal pH (Table 5). Rumen ammonia concentration tended to be lower (10.5 vs. $11.4 \mathrm{mmol} / \mathrm{L} ; P=0.08)$ for MON compared with CON, but no effect was observed with increasing LPL. Increasing LPL in the diet decreased $(P=0.03)$ acetate as proportion of total VFA in a dose-response manner but did not affect propionate as proportion of total VFA, which resulted in a tendency for a decrease $(P=0.088)$ in the ratio of acetate to propionate. Furthermore, inclusion of LPL in the diet increased $(P$ $=0.012$ ) valerate as proportion of total VFA without changes in other VFA composition. However, no difference in VFA composition between $\mathrm{CON}$ and MON were observed.
Changes in bacterial populations at phylum and genus levels by MON and LPL are shown in Figure 1, and only bacteria that were statistically different in population among treatments are shown in Table 6 . The populations of few bacteria were altered by LPL compared with CON. Rikenella and Paludibacter (at genus level) decreased $(P \leq 0.05)$ when LPL increased in the diet. At species level, Treponema bryantii and Bifidobacterium ruminantium linearly decreased $(P \leq$ $0.03)$ with increasing level of LPL in the diet. Changes in bacterial populations by MON were relatively more considerable. Eubacterium, Rikenella, Mucilaginibacter, Paludibacter, Solitalea, and Thioalkalibacter decreased $(P<0.05)$ but Succiniclasticum, Prevotella, Halospirulina, and Fibrobacter increased $(P<0.05)$ with MON compared with CON. At species level, decreases in proportion of Clostridium sp., B. ruminantium, and Thioalkalibacter halophilus and increases in proportions of Ruminococcus albus, Prevotella ruminicola, and Fibrobacter succinogenes were observed $(P<0.05)$ for MON versus CON. Populations of the major archaea in the rumen were not affected by treatments.

\section{DISCUSSION}

To our best knowledge, only 1 study is available in which LPL as a feed additive was examined in dairy cows (see the discussion below). Therefore, because of limited information about LPL in ruminants, studies with dairy cows fed lecithin (a source of LPL) and studies with nonruminant animals fed lecithin or LPL were

Table 4. Effects of lysophospholipids on $\mathrm{N}$ metabolism and balance in dairy cows

\begin{tabular}{|c|c|c|c|c|c|c|c|c|}
\hline \multirow[b]{2}{*}{ Item } & \multicolumn{4}{|c|}{$\operatorname{Diet}^{1}$} & \multirow[b]{2}{*}{ SEM } & \multicolumn{3}{|c|}{$P$-value ${ }^{2}$} \\
\hline & $\mathrm{CON}$ & MON & LLPL & HLPL & & M & M-LPL & Lin \\
\hline $\mathrm{N}$ intake, $\mathrm{g} / \mathrm{d}$ & 566.3 & 562.5 & 574.6 & 592.3 & 29.63 & 0.84 & 0.24 & 0.22 \\
\hline \multicolumn{9}{|l|}{ Milk } \\
\hline $\mathrm{N}, \mathrm{g} / \mathrm{d}$ & 153.7 & 162.3 & 163.4 & 165.7 & 6.59 & 0.09 & 0.58 & 0.024 \\
\hline $\mathrm{N}, \%$ of $\mathrm{N}$ intake & 27.8 & 29.3 & 29.1 & 28.5 & 2.25 & 0.27 & 0.69 & 0.49 \\
\hline \multicolumn{9}{|l|}{ Feces } \\
\hline $\mathrm{N}, \mathrm{g} / \mathrm{d}$ & 224.8 & 214.7 & 218.6 & 234.7 & 14.35 & 0.38 & 0.25 & 0.52 \\
\hline $\mathrm{N}, \%$ of $\mathrm{N}$ intake & 39.7 & 38.1 & 38.2 & 39.7 & 1.79 & 0.34 & 0.57 & 0.84 \\
\hline \multicolumn{9}{|l|}{ Urine } \\
\hline $\mathrm{N}, \mathrm{g} / \mathrm{d}$ & 178.6 & 155.7 & 163.1 & 161.7 & 12.07 & $<0.01$ & 0.24 & 0.016 \\
\hline $\mathrm{N}, \%$ of $\mathrm{N}$ intake & 31.5 & 27.7 & 28.3 & 27.3 & 1.39 & 0.04 & 0.95 & 0.023 \\
\hline Urea $\mathrm{N}, \mathrm{g} / \mathrm{d}$ & 125.1 & 125.5 & 128.8 & 127.6 & 13.82 & 0.97 & 0.79 & 0.79 \\
\hline Urea $\mathrm{N}, \%$ of total $\mathrm{N}$ & 80.2 & 82.8 & 80.0 & 78.1 & 5.80 & 0.11 & 0.55 & 0.23 \\
\hline Uric acid, mmol/d & 35.5 & 28.4 & 33.5 & 31.4 & 3.24 & 0.15 & 0.34 & 0.40 \\
\hline Allantoin, mmol/d & 324.9 & 275.6 & 337.5 & 359.1 & 40.23 & 0.17 & 0.045 & 0.34 \\
\hline $\mathrm{PD},{ }^{3} \mathrm{mmol} / \mathrm{d}$ & 358.3 & 301.9 & 373.9 & 388.5 & 41.82 & 0.11 & 0.027 & 0.36 \\
\hline $\mathrm{N}$ retained, $\mathrm{g} / \mathrm{d}$ & 9.0 & 29.6 & 25.1 & 30.0 & 16.11 & 0.26 & 0.89 & 0.23 \\
\hline $\mathrm{N}$ retained, $\%$ of $\mathrm{N}$ intake & 1.2 & 4.9 & 4.3 & 4.6 & 2.81 & 0.26 & 0.86 & 0.27 \\
\hline
\end{tabular}

${ }^{1} \mathrm{CON}=$ control; MON $=$ monensin $(16 \mathrm{mg} / \mathrm{kg}$ of dietary DM $) ; \mathrm{LLPL}=0.05 \%$ lysophospholipids; HLPL $=0.075 \%$ lysophospholipids.

${ }^{2} \mathrm{M}=\mathrm{CON}$ versus MON; M-LPL $=\mathrm{M}$ versus LLPL + HLPL; Lin $=$ linear effect of LPL.

${ }^{3}$ Purine derivatives (uric acid + allantoin). 
used to discuss our results. The product of LPL used in the current study is hydrolyzed soy lecithin and includes phospholipids and free fatty acids as well as LPL $(6 \%)$ according to the manufacturer (Easy Bio Inc.).

The current study included a diet supplemented with monensin (i.e., MON) as one of the treatments because of the following reasons. Monensin has known effects as a feed additive in dairy cows, such as increasing milk yield, feed efficiency, and dietary $\mathrm{N}$ utilization and altering rumen bacterial population (Russell and Houlihan, 2003; Duffield et al., 2008). Because similar production effects of LPL were hypothesized (although mode of actions are different), MON was used as a positive control. Second, Polycarpo et al. (2016) observed that feeding LPL decreased gram-positive bacteria in the jejunum of broilers in a certain dietary condition (a corn-based diet containing beef tallow), and monensin is known to selectively depress gram-positive bacteria in the rumen (Russell and Houlihan, 2003). Therefore, ruminal fermentation and bacterial population altered by MON were used as a reference in the current study.

Lysophospholipids as a feed additive have been examined mostly with nonruminant animals, where increased growth rates and feed efficiency have been observed by feeding LPL to chicken and pigs (Zhao et al., 2015, 2017; Polycarpo et al., 2016; Zampiga et al., 2016). In lactating sows fed a diet with LPL $(0.03 \%$ in dietary DM), increased milk fat, protein, and lactose concentrations were found (Zhao et al., 2017). Although production data from a Latin square design with 2 squares need to be interpreted carefully, the current study with dairy cows also observed positive effects of LPL on production where milk yield, feed efficiency, and milk protein yield were increased and milk fat yield tended to be increased compared with CON. In a study by Rico et al. (2017), however, dairy cows fed a diet with LPL $(10 \mathrm{~g} / \mathrm{d} ; \sim 0.035 \%$ of dietary DM) did not increase milk yield, although milk fat content was increased. The discrepancy between Rico et al. (2017) and the current study is difficult to explain. However, it could be partially attributed to different products of LPL used in the studies. Depending on the sources of phospholipids and process of enzymatic hydrolysis of phospholipids to produce LPL, proportion of LPL in the product can vary. In addition, the dosage level of LPL was greater in the current study compared with the study by Rico et al. (2017). In nonruminant animals, LPL were widely examined as feed additives, and production responses to LPL were quite consistent (growth rate and feed efficiency; Zhao et al., 2015; Polycarpo et al., 2016; Zhao and Kim, 2017). This indicates that the degree of ruminal bypass of LPL might be critical for positive and consistent production responses to LPL in dairy cows [Jenkins et al., 1989; escaping rumen degradation of part of phospholipids (source of LPL) was observed in this continuous culture study].

No studies are available that have examined effects of supplemental LPL on nutrient digestibility in dairy cows. In nonruminant animals, feeding LPL increased dietary nutrient absorption and digestibility, which are the major positive effects of supplemental LPL (Zhang et al., 2010; Zampiga et al., 2016). However, we observed a tendency for decreased DM and OM apparent digestibility in the current study. Previously, high inclusion of lecithin (2 to $6 \%$ in dietary DM) decreased fiber and OM digestion in vitro (Jenkins et al., 1989), which occurred due to increased PUFA in the rumen from supplemented lecithin. However, the dosage rate of LPL in the current study was much lower (0.05 and $0.075 \%$ of dietary DM) and additional PUFA supply with LPL likely did not cause the trend for decreased apparent digestibility of DM and OM. Instead, it may have been caused, at least in part, by a numerical decrease in apparent digestibility of NDF for LPL versus

Table 5. Effects of lysophospholipids on ruminal fermentation in dairy cows

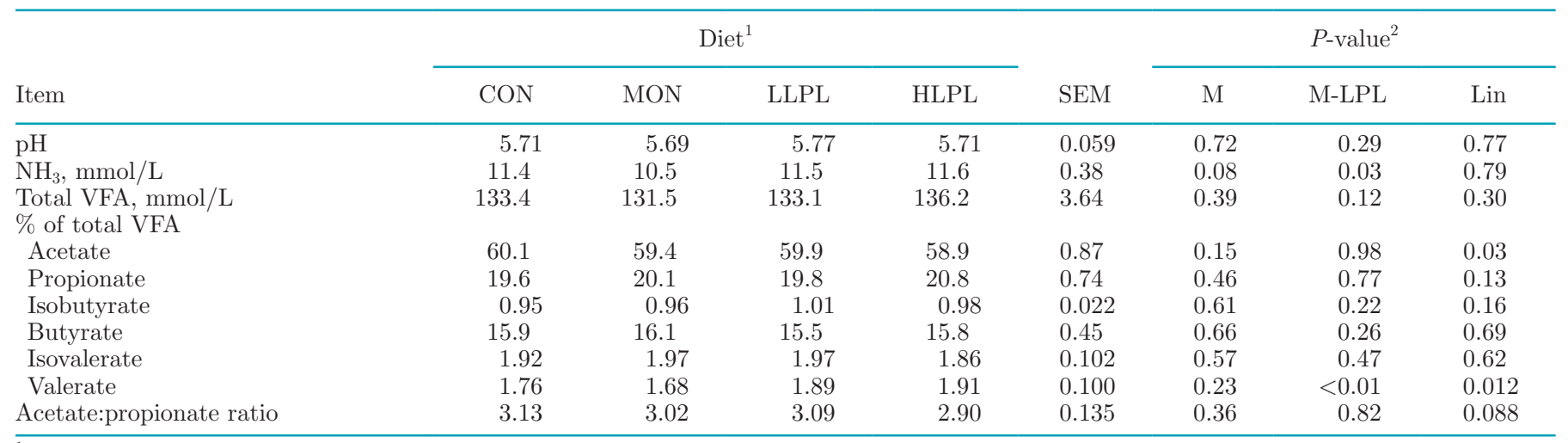

${ }^{1} \mathrm{CON}=$ control; MON $=$ monensin $(16 \mathrm{mg} / \mathrm{kg}$ of dietary DM $) ; \mathrm{LLPL}=0.05 \%$ lysophospholipids; HLPL $=0.075 \%$ lysophospholipids.

${ }^{2} \mathrm{M}=\mathrm{CON}$ versus MON; M-LPL $=\mathrm{M}$ versus LLPL + HLPL; Lin = linear effect of LPL. 

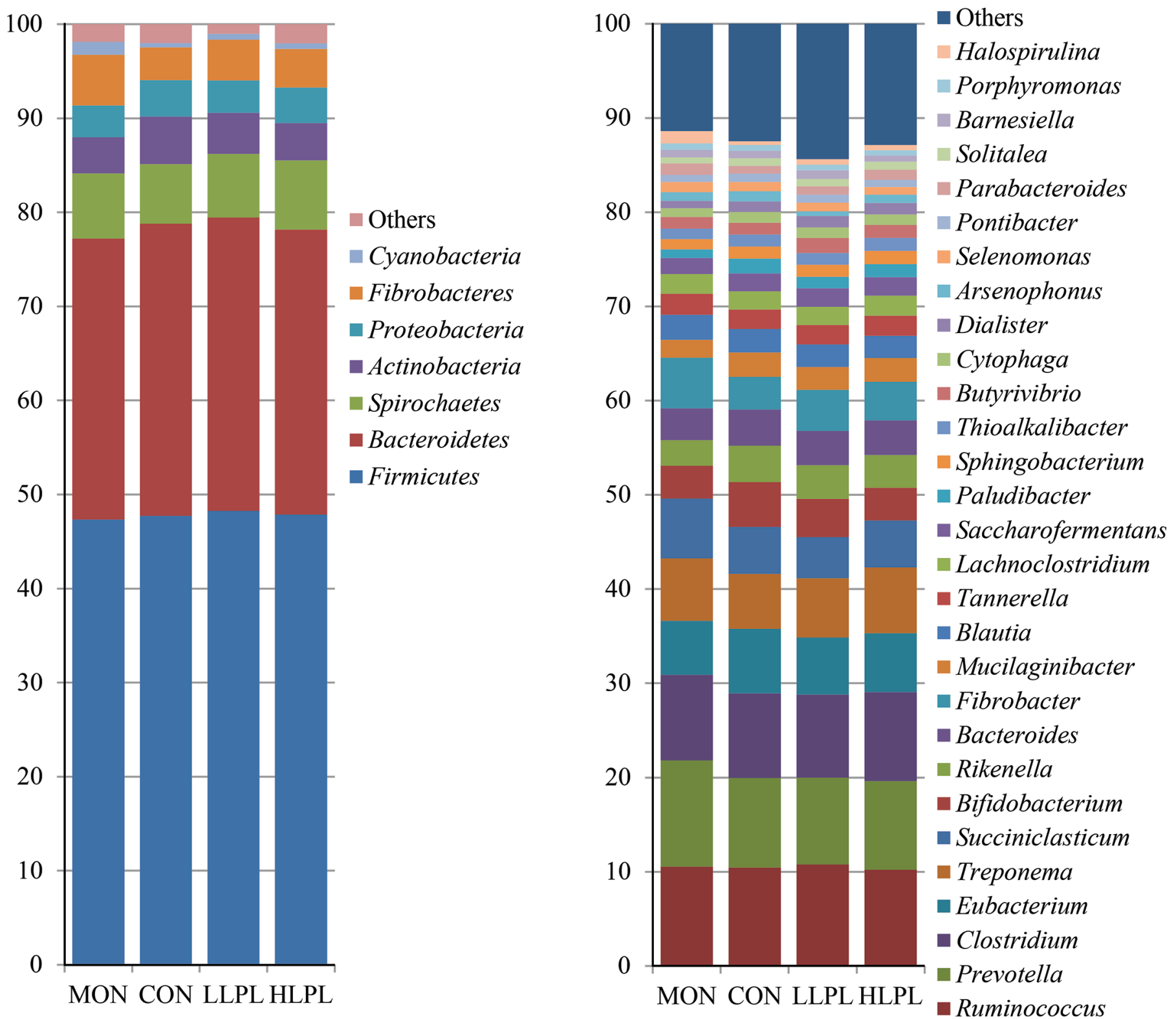

Figure 1. Bacterial populations at phylum (left) and genus (right) levels in the rumen at $4 \mathrm{~h}$ after feeding a diet supplemented with monensin or lysophospholipids. $\mathrm{CON}=$ control; $\mathrm{MON}=$ monensin $(16 \mathrm{mg} / \mathrm{kg}$ of dietary DM $) ; \mathrm{LLPL}=0.05 \%$ lysophospholipids; HLPL $=0.075 \%$ lysophospholipids.

CON (SEM of NDF digestibility was greater by a $1 \%$ unit compared with that of DM and OM digestibility, likely causing no statistical differences among treatments). If NDF apparent digestibility was negatively affected by LPL in this study, it is not known how LPL decreased apparent digestibility of NDF in the current study because emulsifiers (e.g., Tween 80) can increase cellulolytic enzyme activities and enhance fiber degradation in the rumen (Hwang et al., 2008). However, variable production responses to different types of emulsifiers in dairy cows were also reported (Wieland et al., 1993). In addition, although a trend for decreased DM and OM was observed with increasing LPL, the decrease is unlikely to be relevant biologically.

Increases in milk $\mathrm{N}$ secretion with increasing LPL in the diet might be, at least in part, a consequence of decreases in urinary $\mathrm{N}$ excretion. This may suggest that dietary $\mathrm{N}$ was absorbed in more utilizable forms of $\mathrm{N}$ for protein synthesis in the body (e.g., AA supply or profile). It was reported that some phospholipids escaped rumen microbial degradation in a continuous culture experiment (Jenkins et al., 1989). If this was the 
Table 6. Effects of lysophospholipids on ruminal bacterial profile (\% of total sequence reads) in dairy cows

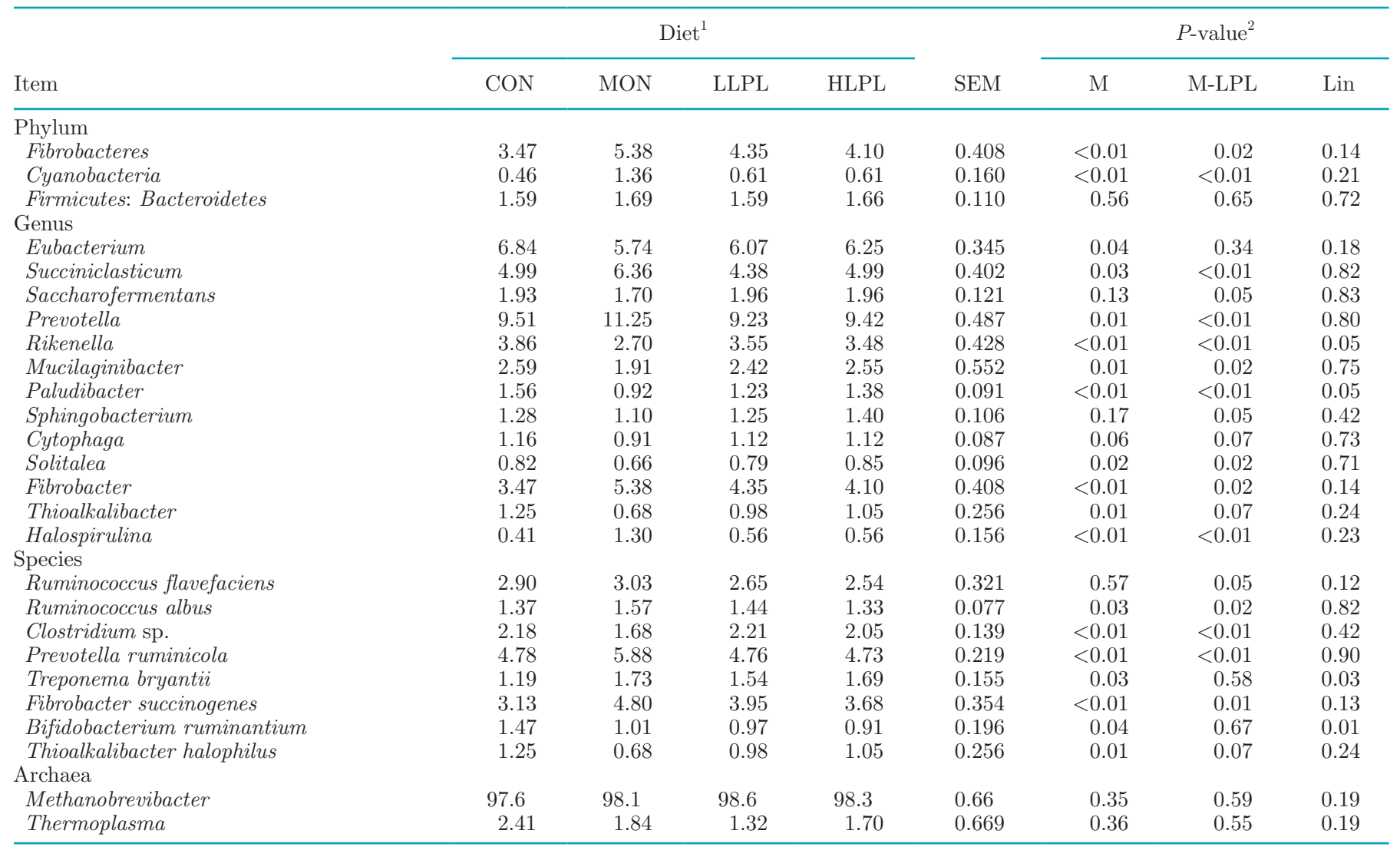

${ }^{1} \mathrm{CON}=$ control; $\mathrm{MON}=$ monensin $(16 \mathrm{mg} / \mathrm{kg}$ of dietary DM); LLPL $=0.05 \%$ lysophospholipids; HLPL $=0.075 \%$ lysophospholipids.

${ }^{2} \mathrm{M}=\mathrm{CON}$ versus MON; M-LPL $=\mathrm{M}$ versus LLPL + HLPL; Lin = linear effect of LPL.

case in the current study, LPL may have improved the absorption of AA or peptides in the gut as observed in nonruminant animals. Tagesson et al. (1985) observed potential increases in permeability of macromolecules such as proteins in the gut of rats fed LPL. Brautigan et al. (2017) recently found that LPL supplementation upregulated various genes in intestinal epithelium that are involved in nutrient absorption and increased villus length and width, potentially increasing nutrient absorption in chickens. In the current study, apparent digestibility of dietary $\mathrm{CP}$, MUN, and urinary urea excretion were not affected with increasing LPL, indicating that more studies are needed to explore the mechanism of LPL on $\mathrm{N}$ utilization. However, it cannot be ignored that purine derivatives excretion was greater for LPL compared with MON significantly and CON numerically, suggesting that LPL likely increased microbial protein supply. Furthermore, potential positive effects of LPL on ruminal absorption of various feed fermentation end products (e.g., VFA) should be further studied due to the positive effects of LPL on intestinal epithelium gene expression and villus as indicated previously (Brautigan et al., 2017).
The major changes observed in ruminal fermentation were reduced proportion of acetate in total VFA with no differences in propionate proportion, resulting in a tendency for decreasing the ratio of acetate to propionate. Studies that examined effects of LPL on ruminal fermentation are extremely limited. When alfalfa hay supplemented with soy lecithin was incubated, inconsistent results of acetate:propionate ratio were observed from 5 in vitro incubations (Jenkins et al., 1989). In that study, when purified phospholipids were incubated with alfalfa hay, proportion of propionate linearly increased with increasing phospholipids where decreased NDF digestibility was observed. In the current study, the slight decrease in acetate proportion and the ratio of acetate to propionate may have been associated with a numerical decrease in apparent digestibility of NDF (see the previous discussion). Although other branchedchain VFA were not affected, increased proportion of valerate with increasing LPL might be partially indicative of decreased NDF digestibility and proportion of acetate in the rumen because valerate is one of the acids required by cellulolytic bacteria to stimulate fiber digestion (Andries et al., 1987). Overall, changes in 
acetate and propionate concentrations without altering total VFA concentration indicate that LPL might affect the ruminal bacterial profile. However, the degree of changes in the microbial profile by LPL was not large according to no changes in ruminal $\mathrm{pH}$ and $\mathrm{NH}_{3}$ and the degree of changes in VFA by LPL, which is in agreement with an in vitro study by Sontakke et al. (2014). In this study, LPL were extracted from rice bran and used for incubation where the effects of LPL on ruminal fermentation were minimal. Relatively small effects of LPL on ruminal fermentation are also supported by minimal changes in bacterial populations observed in the current study. The number of bacteria at genus and species levels that were altered by LPL was very small. In addition, even though some changes were observed, the degree of changes in populations by LPL was likely trivial to contribute to significantly altering ruminal fermentation. For example, T. bryantii is often found in the rumen as a strict anaerobe. Although this bacterium does not have the ability to degrade fiber, it can stimulate fiber degradation of cellulolytic bacteria (Kudo et al., 1987). The proportion of this bacterium increased with increasing LPL from 1.19 to $1.69 \%$ in the current study. However, this did not increase proportions of cellulolytic bacteria ( $F$. succinogenes, $R$. albus, and Ruminococcus flavefaciens). In addition, increases in apparent NDF digestibility and ruminal acetate concentration were not observed in the current study. Bifidobacterium ruminantium can produce acetate and lactate from glucose in the rumen (Biavati and Mattarelli, 1991). A decrease in population of $B$. ruminantium from 1.01 to $0.91 \%$ with increasing LPL might be in line with decreases in ruminal acetate concentration in the current study. However, the population of this bacterium is small in the rumen and it is not known how much the $10 \%$ decrease in the population of B. ruminantium by LPL affected ruminal fermentation (e.g., acetate production).

The effects of MON versus CON observed in the current study are generally in agreement with results in the literature. A meta-analysis by Duffield et al. (2008) indicated that cows fed a diet supplemented with monensin decreased DMI by $0.3 \mathrm{~kg}$ but increased milk yield by $0.7 \mathrm{~kg} / \mathrm{d}$, resulting in increased production efficiency (energy yield/energy intake) by $2.5 \%$. Although DMI was not affected by MON, milk yield and feed efficiency increased for MON versus CON in the current study. Milk fat concentration, however, decreased for MON versus CON, which was also one of the known effects of monensin in dairy cows (Duffield et al., 2008). Feeding monensin to dairy cows can increase dietary $\mathrm{N}$ utilization efficiency by lowering ruminal ammonia production (Russell and Houlihan, 2003), which is in agreement with the current study. Proportions of ruminal bacteria were altered relatively more considerably by MON compared with LPL. An increase in Prevotella and no depression of cellulolytic bacterial population (Ruminococcus and Fibrobacter) are in agreement with a study by Weimer et al. (2008). Bacterial profile (species) altered, and the degree of changes in proportion were different between MON and LPL. This suggests that although positive production responses to MON and LPL were similarly observed (i.e., milk yield, feed efficiency, and dietary $\mathrm{N}$ utilization), the mode of action was different between MON and LPL. In the current study, the mode of action of LPL for positive production could not be determined. However, according to a different mode of action between MON and LPL, the combination of LPL and MON may have additive positive effects on production in dairy cows.

\section{CONCLUSIONS}

Supplementation of a lactation diet with LPL increased milk yield and feed efficiency in a dose-response manner, and the positive production response was similar between LPL and MON. Although more studies with large numbers of animals are needed to confirm, the increased production by LPL in the current study is in agreement with that found in nonruminant animals fed LPL. However, apparent digestibility of DM and OM tended to decrease with increasing LPL, which were not observed in nonruminant animals. A diet with LPL increased milk $\mathrm{N}$ secretion and decreased urinary $\mathrm{N}$ excretion with minimal effects of LPL on ruminal fermentation and bacterial populations. Although responses in production and dietary $\mathrm{N}$ utilization to LPL were similar to responses to MON, the mechanism between LPL and MON was likely different according to ruminal fermentation characteristics. Therefore, further studies are needed to confirm our results and explore the mode of action of LPL in dairy cows.

\section{ACKNOWLEDGMENTS}

The authors thank P. A. Dieter (The Ohio State University, Wooster) for assistance with sample collection and laboratory analysis and the Krauss Dairy Farm staff (Ohio Agricultural Research and Development Center, Wooster) for care of the experimental animals. Research was supported by Easy Bio Inc. (Seoul, South Korea) and partially funded from Hatch funds administered by U.S. Department of Agriculture and state and federal funds appropriated to the Ohio Agricultural Research and Development Center, The Ohio State University. 


\section{REFERENCES}

Andries, J. I., F. X. Buysse, D. L. Debrabander, and B. G. Cottyn 1987. Isoacids in ruminant nutrition-Their role in ruminal and intermediary metabolism and possible influences on performancesA review. Anim. Feed Sci. Technol. 18:169-180.

AOAC International. 2000. Official Methods of Analysis. Vol. 1 and 2. 17th ed. AOAC International, Gaithersburg, MD.

Biavati, B., and P. Mattarelli. 1991. Bifidobacterium ruminantium sp. nov. and Bifidobacterium merycicum sp. nov. from the rumens of cattle. Int. J. Syst. Bacteriol. 41:163-168.

Brask, M., M. R. Weisbjerg, A. L. F. Hellwing, A. Bannink, and P. Lund. 2015. Methane production and diurnal variation measured in dairy cows and predicted from fermentation pattern and nutrient or carbon flow. Animal 9:1795-1806.

Brautigan, D. L., R. Li, E. Kubicka, S. D. Turner, J. S. Garcia, M. L. Weintraut, and E. A. Wong. 2017. Lysolecithin as feed additive enhances collagen expression and villus length in the jejunum of broiler chickens. Poult. Sci. 96:2889-2898.

Chaney, A. L., and E. P. Marbach. 1962. Modified reagents for determination of urea and ammonia. Clin. Chem. 8:130-132.

Chen, X. B., J. Mathieson, F. D. D. Hovell, and P. J. Reeds. 1990 Measurement of purine derivatives in urine of ruminants using automated methods. J. Sci. Food Agric. 53:23-33.

Doane, M., and S. Sarenbo. 2014. Antibiotic usage in 2013 on a dairy CAFO in NY State, USA. Infect. Ecol. Epidemiol. 4. https://doi .org/10.3402/iee.v4.24259.

Dowd, S. E., T. R. Callaway, R. D. Wolcott, Y. Sun, T. McKeehan, R. G. Hagevoort, and T. S. Edrington. 2008. Evaluation of the bacterial diversity in the feces of cattle using $16 \mathrm{~S}$ rDNA bacterial tag-encoded FLX amplicon pyrosequencing (bTEFAP). BMC Microbiol. 8:125.

Duffield, T. F., A. R. Rabiee, and I. J. Lean. 2008. A meta-analysis of the impact of monensin in lactating dairy cattle. Part 2. Production effects. J. Dairy Sci. 91:1347-1360.

Hristov, A. N., T. R. Callaway, C. Lee, and S. E. Dowd. 2012. Rumen bacterial, archaeal, and fungal diversity of dairy cows in response to ingestion of lauric or myristic acid. J. Anim. Sci. 90:4449-4457.

Hwang, I. H., C. H. Lee, S. W. Kim, H. G. Sung, S. Y. Lee, S. S. Lee, H. Hong, Y. C. Kwak, and J. K. Ha. 2008. Effects of mixtures of Tween 80 and cellulolytic enzymes on nutrient digestion and cellulolytic bacterial adhesion. Asian-australas. J. Anim. Sci. 21:1604-1609.

Jenkins, T. C., T. Gimenez, and D. L. Cross. 1989. Influence of phospholipids on ruminal fermentation in vitro and on nutrient digestion and serum lipids in sheep. J. Anim. Sci. 67:529-537.

Kamande, G. M., J. Baah, K. J. Cheng, T. A. McAllister, and J. A. Shelford. 2000. Effects of Tween 60 and Tween 80 on protease activity, thiol group reactivity, protein adsorption, and cellulose degradation by rumen microbial enzymes. J. Dairy Sci. 83:536-542.

Kudo, H., K. J. Cheng, and J. W. Costerton. 1987. Interactions between Treponema bryantii and cellulolytic bacteria in the in vitro degradation of straw cellulose. Can. J. Microbiol. 33:244-248.

Lee, C., A. N. Hristov, T. W. Cassidy, K. S. Heyler, H. Lapierre, G. A. Varga, M. J. de Veth, R. A. Patton, and C. Parys. 2012. Rumenprotected lysine, methionine, and histidine increase milk protein yield in dairy cows fed a metabolizable protein-deficient diet. J. Dairy Sci. 95:6042-6056.

Lee, C., J. Oh, A. N. Hristov, K. Harvatine, M. Vazquez-Anon, and G. I. Zanton. 2015. Effect of 2-hydroxy-4-methylthio-butanoic acid on ruminal fermentation, bacterial distribution, digestibility, and performance of lactating dairy cows. J. Dairy Sci. 98:1234-1247.

Mao, S. Y., G. Zhang, and W. Y. Zhu. 2008. Effect of disodium fumarate on ruminal metabolism and rumen bacterial communities as revealed by denaturing gradient gel electrophoresis analysis of $16 \mathrm{~S}$ ribosomal DNA. Anim. Feed Sci. Technol. 140:293-306.

Maron, D. F., T. J. S. Smith, and K. E. Nachman. 2013. Restrictions on antimicrobial use in food animal production: An international regulatory and economic survey. Global. Health 9:48.

NRC. 2001. Nutrient Requirements of Dairy Cattle. 7th rev. ed. Natl. Acad. Sci., Washington, DC.
Polycarpo, G. V., M. F. C. Burbarelli, A. C. P. Carao, C. E. B. Merseguel, J. C. Dadalt, S. R. L. Maganha, R. L. M. Sousa, V. C. Cruz-Polycarpo, and R. Albuquerque. 2016. Effects of lipid sources, lysophospholipids and organic acids in maize-based broiler diets on nutrient balance, liver concentration of fat-soluble vitamins, jejunal microbiota and performance. Br. Poult. Sci. 57:788-798.

Rico, D. E., Y. Ying, and K. J. Harvatine. 2017. Short communication: Effects of lysolecithin on milk fat synthesis and milk fatty acid profile of cows fed diets differing in fiber and unsaturated fatty acid concentration. J. Dairy Sci. 100:9042-9047.

Rock River Laboratory. 2018. Animal nutrition services. Accessed Jan. 15, 2019. https://www.rockriverlab.com/pages/Animal-Nutrition .php.

Russell, J. B., and A. J. Houlihan. 2003. Ionophore resistance of ruminal bacteria and its potential impact on human health. FEMS Microbiol. Rev. 27:65-74.

Sjaunja, L. O., L. Bævre, L. Junkkarinen, J. Pedersen, and J. Setälä. 1990. A Nordic proposal for an energy corrected milk (ECM) formula. Pages 156-157 in Proc. 27th Session of International Committee for Recording Productivity of Milk Animals (ICRPMA). Eur. Assoc. Anim. Prod. Publ. No. 50. Eur. Assoc. Anim. Prod., Wageningen, the Netherlands.

Sontakke, U. B., H. Kaur, A. K. Tyagi, M. Kumar, and S. A. Hossan. 2014. Effect of feeding rice bran lyso-phospholipids and rumen protected fat on feed intake, nutrient utilization and milk yield in crossbred cows. Indian J. Anim. Sci. 84:998-1003.

Tagesson, C., L. Franzen, G. Dahl, and B. Westrom. 1985. Lysophosphatidylcholine increases rat ileal permeability to macromolecules. Gut 26:369-377.

Tebbe, A. W., and W. P. Weiss. 2018. Evaluation of creatinine as a urine marker and factors affecting urinary excretion of magnesium by dairy cows. J. Dairy Sci. 101:5020-5032.

Tyrrell, H. F., and J. T. Reid. 1965. Prediction of the energy value of cow's milk. J. Dairy Sci. 48:1215-1223.

Valadares, R. F. D., G. A. Broderick, S. C. Valadares, and M. K. Clayton. 1999. Effect of replacing alfalfa silage with high moisture corn on ruminal protein synthesis estimated from excretion of total purine derivatives. J. Dairy Sci. 82:2686-2696.

VandeHaar, M. J., L. E. Armentano, K. Weigel, D. M. Spurlock, R. J. Tempelman, and R. Veerkamp. 2016. Harnessing the genetics of the modern dairy cow to continue improvements in feed efficiency. J. Dairy Sci. 99:4941-4954.

Weimer, P. J., D. M. Stevenson, D. R. Mertens, and E. E. Thomas, 2008. Effect of monensin feeding and withdrawal on populations of individual bacterial species in the rumen of lactating dairy cows fed high-starch rations. Appl. Microbiol. Biotechnol. 80:135-145.

Wieland, T. M., X. Lin, and J. Odle. 1993. Utilization of mediumchain triglycerides by neonatal pigs - Effects of emulsification and dose delivered. J. Anim. Sci. 71:1863-1868.

Zampiga, M., A. Meluzzi, and F. Sirri. 2016. Effect of dietary supplementation of lysophospholipids on productive performance, nutrient digestibility and carcass quality traits of broiler chickens. Ital. J. Anim. Sci. 15:521-528.

Zhang, B. K., H. T. Li, Y. M. Guo, and D. Q. Zhao. 2010. Effect of fat source and levels, with lysophospholipids, on broiler performance, fatty acid digestibility and apparent metabolizable energy content in feed. J. Dairy Sci. 93(Suppl.):212. (Abstr.)

Zhao, P. Y., and I. H. Kim. 2017. Effect of diets with different energy and lysophospholipids levels on performance, nutrient metabolism, and body composition in broilers. Poult. Sci. 96:1341-1347.

Zhao, P. Y.. H. L. Li, M. M. Hossain, and I. H. Kim. 2015. Effect of emulsifier (lysophospholipids) on growth performance, nutrient digestibility and blood profile in weanling pigs. Anim. Feed Sci. Technol. 207:190-195.

Zhao, P. Y., Z. F. Zhang, R. X. Lan, W. C. Liu, and I. H. Kim. 2017. Effect of lysophospholipids in diets differing in fat contents on growth performance, nutrient digestibility, milk composition and litter performance of lactating sows. Animal 11:984-990. 